\title{
AUTONOMOUS ACTIVIST-RESEARCH The case of the squatters' movement in Madrid
}

\author{
INVESTIGACIÓN ACTIVISTAAUTÓNOMA \\ El caso del movimiento de okupaciones de Madrid
}

\author{
Miguel Ángel Martínez López miguelam@cps.ucm.es \\ Universidad Complutense de Madrid (UCM). Spain
}

ELÍSABETH LORENZI FERNÁNDEZ elisabeth.lorenzi@gmail.com

Universidad Nacional de Educación a Distancia (UNED). Spain

\begin{abstract}
Citizen participation has been recently incorporated in the design and implementation of different public policies but participants have often criticised that there is little room for autonomous modes of citizen participation within institutional frameworks. Which are the specific features of autonomous processes of citizen participation compared to the most institutional ones? How does autonomous participation develop? This article deals with the methodological aspects of autonomous participation. In doing so, we will present an experience of autonomous activist-research within the squatters' movement of Madrid which lasted for two and a half years. In particular, we focus on the methodological decisions taken by activist-researchers and describe the major contributions of this participatory process. We argue that such an activist-research process was based upon three different strategies which provided a productive framework for the participants' involvement: a) an open, horizontal and self-managed group of activist-researchers; b) an open-source and copy-left commitment in order to fulfill an equal access to the production of knowledge; c) a qualitative and comprehensive methodology which allowed to gather a wide range of information taking into account the social diversity within the squatters' movement.
\end{abstract}

\section{KEYWORDS}

Activist-research; Autonomous citizen participation; Methodology of social sciences; Reflexivity; Squatters' movement.

\section{Resumen}

La participación ciudadana ha sido recientemente incorporada en el diseño e implementación de diferentes políticas públicas, pero quienes participan han criticado a menudo que existe poco espacio para las modalidades autónomas de participación ciudadana dentro de los marcos institucionales. ¿Cuáles son los rasgos específicos de los procesos autónomos de participación ciudadana comparados a los más institucionales? ¿Cómo se desarrolla la participación autónoma? Este artículo expone algunos aspectos metodológicos de la participación autónoma. Presentamos una experiencia de investigación activista autónoma desarrollada con el movimiento de okupaciones de Madrid durante dos años y medio. En particular, nos centramos en las decisiones metodológicas adoptadas por los investigadores-activistas y describimos las principales contribuciones de este proceso participativo. De este modo, argumentamos que este proceso de investigación-activista se fundamentó en tres estrategias que proporcionaron un entorno productivo para la implicación de los participantes: a) un grupo de investigadores activistas abierto, horizontal y autogestionado; b) un compromiso con el "open-source" y "copy-left" para garantizar un acceso igualitario a la producción de conocimiento; c) un enfoque metodológico cualitativo y comprensivo que permitió reunir un amplio rango de informaciones e integrar la diversidad social presente en el movimiento de okupaciones.

\section{Palabras clave}

Investigación-activista; Metodología de las ciencias sociales; Movimiento de okupaciones; Participación ciudadana autónoma; Reflexividad. 


\section{INTRODUCTION}

Like Alice in Wonderland, social scientists deal with social reality as we were setting up a looking glass and, simultaneously, as we were pointing to the illusions that this and any other social construction involve. Our major goal is to offer an accurate image of the social world around. This, however, includes our own image. It also implies that, at the same time, wedisbelieve the usual reflections provided by common sense and popular explanations. Real life is what we see and perceive, as well as too many other hidden things (events, people, information, networks, processes) that we do not see so easily. Social science is about uncovering the social relations and social facts that make all these things happen. Regardless how evident they appear to our eyes, our scientific purpose is to determine how social facts influence individual and collective behaviours. However, the notions of 'science' and 'scientific method' have been very controversial within the field of social sciences. The most extreme positivists argued for an unified conception of natural and social sciences based on the same goals of objectivity, the same distant attitudes towards the reality-out-there and the same empirical-analyticaland-causal approaches. Whilst, long-standing debates around this issue led to a more pluralistic notion of both 'social sciences' and the 'scientific methods'. Critics of positivism argue that the social world differs substantially from the natural world, even if the former depends hierarchically on the latter. It is also possible to identify causal relationships within the social world but those relationships only provide partial accounts of the social facts and relationships which, above all, have different meanings for different social groups. In addition, when social scientists adopt and apply specific methods of social research, and when our results are socially spread out, we are usually participating in the social reality in a more intense and controversial way than natural scientists - this leaving apart the technological consequences of any kind of knowledge. Clouds, insects and planets do not care about human theories about them, but humans do care and react even during the process of being subjected to scrutiny (Galtung 1977, Wilden 1987, Woolgar 1988, De Sousa et al. 2003).

According to these last assumptions, Participatory Action-Research (PAR) in general, and Activist-Research (AvR) in particular, historically appeared as a proposal to make more explicit the involvement of both researchers and people subjected to research. This awareness or reflexivity has political implications since it implies overt debates about social inequalities and power relationships during the process of research. The methodological design and implementation is thus a matter of social participation in which the scientists' contributions are crucial to inform, help or guide the whole process. Most of the decisions are collectively discussed and different types of people are able to contribute at different stages of the research and perform different tasks. In the end, social scientists are not the only ones responsible for the production of social knowledge, and this does not necessarily demerit its scientific quality in terms of uncovering the crucial social relationships and facts that constrain our lives. According to the major proponents of PAR (Fals Borda 1985, Rahman 1991, Park 1992, Reason 1994, Villasante 2006, Greenwood 
2007) this approach combines, in a flexible and creative manner, multiple research techniques in the production of knowledge, without necessarily excluding those coming from positivist conceptions of social sciences. The scientific and political goals of the process, the available resources and the theoretical premises underlying the research questions, will guide all the participants to make the most convenient and adequate methodological decisions. Therefore, theory and practice are mutually connected in the form of a spiral, zigzag or continuous dialectics. By 'theory' we mean all the previous knowledge and worries that participants bring about to the research process. Theory is also nurtured by the knowledge produced by the PAR / AvR process, included learning experience of participants and different forms of communication triggered by them. By 'practice' we mean the actions taken by the participants in order to change their surrounding world. These actions would be closely connected to the knowledge produced along the research process. Obviously, acting out from a PAR process does not immediately entail a social change. More frequently, what such a process generates is potentialities of social change rather than a powerful social change itself. Most of the literature (Cancian 1993, Villasante 2006) point out different levels of political outcomes, usually below the initial expectations, and conflicts with the researchers' academic interests and the institutional constraints are often mentioned (Petras and Porpora 1993). The participation of subordinated, underprivileged, exploited and deprived social groups into PAR processes does not imply, mechanically, that their living conditions will improve. The main reason is that all these groups are obliged to interact with social scientists, authorities and wealthier groups who can hinder the emancipatory strategies outlined during the process.

Activist or participatory social scientists do not abandon their scientific skills and concerns in order to become full-time activists. Rather, they aim at combining both social dimensions of their research activity in a virtuous, yet variable, manner. Their political involvement in a participatory research process may adopt different forms, these being useful in different degrees and forms of relevance for the production of knowledge. For example, a precise selection of informants, the economic and material resources needed, or the distinction of controversial points within ongoing local debates, may be obtained more efficiently by activist researchers than by conventional ones. Hence, we do not mean that social researchers can be absolutely free to chose any kind of methodological approach for any particular situation. Many constraints stem from the researchers' institutional affiliations, from the type of social and political organisations they work with, form the political context, from the available resources, from previous historical experiences, etc.

Activist-Research (AvR) -or 'militant research' (Malo et al. 2004, Shukaitis et al. 2007, Fuster 2009, Cox and Flesher 2009) - may be defined as one of the types of PAR processes through which researchers pursue more effectively the goals of social change linked to the political goals of the social groups, organisations and movements involved. Compared to most PAR approaches, AvR emphasises as much as possible the autonomy of those who promote the research process. Ideally, this would involve a complete self-research process without the need of external help, although some expert 
researchers may be already part of the collective who launch and conduct the process. 'Autonomy' means, basically, that State authorities, for-profit corporations, external organisations and non-activist individuals are not considered stakeholders in AvR processes. They are intentionally excluded. And what about social scientists? They are welcome just in case they feel themselves as part of the self-researched group, organisation or movement, in terms of sharing their political goals and participating in their current political activities. Their militant identity, thus, acquires priority over their scientific one, although the latter is essential to perform the most technical aspects of the research. In practice, autonomy is not usually absolute because some particular resources and ties with external bodies may be inevitable for most participants.

According to Zamosc (1992), activist-researchers differ from simple committedresearchers (or, say, organic and critical intellectuals: Cox 1998) because of the addition of 'synergy' to 'sympathy'-and-'empathy'. Committed-researchers just aim to produce sympathetic knowledge that can be useful for the emancipatory goals of a subordinated group, with no need of their own immersion into this group. Activist-researchers, on the contrary, are called to produce knowledge from within the group's experience (empathy) and to engage themselves into its political practices (synergy). Sympathy is taken fro granted in AvR, but not enough. Empathy, on the other side, requires dissent and critical thinking. These are a sort of fundamental rights-and-duties for activist researchers so that they should be present in the definition and realization of strategies, as part of a synergic collaboration. Thus, researching from within and with activists, means to merge and to share knowledge -even critically and conflictively. This involves that the production of knowledge is closely connected with the sharing of knowledge. As Jimeno (2004) argues, activist-researchers do act as citizens when they share their skills. On the other hand, activists alone are also spontaneous and regular producers of social knowledge. They do define concepts, they make judgments about both their environment and their own internal dynamics, they gather and accumulate different sorts of information and, not the least, they base their decisions and actions upon pretended rational analysis. In sum, activists are reflexive practitioners, which means that an AvR process may not be so disturbing for them as a non-participant may expect.

Since the 1990s, the increasing utilization of the term 'participation' in public policies runs in parallel to the decreasing attention paid to the material and cultural conditions that constrain the engagement of people in public affairs (Young 1990: chapter II; Martínez 2011a). Participation has been institutionalised (Blackburn et al. 1998, Cooke et al. 2001), subjected to market strategies of city governance (Borja and Castells 1997) and mostly restricted to what Arnstein (1969) called placation, therapy, and manipulation. Although many local governments accepted or even promoted participatory procedures in order to achieve legitimation of their planning schemes, deliberation and voting under time-pressure were usually showed as their most positive results (Martínez 2011b, Eckardt 2011). Today, too many social groups are still excluded from participatory processes, relevant decisions are not publicly debated, and institutional participation tends to lack sufficient depth and duration. In addition, the production of outstanding and reli- 
able knowledge is rarely one of the explicit purposes in the experiences of institutional participation. Needless to say, the representative model of liberal democracy, the rule of powerful elites and the never-ending impulse to the city growth-machine coalitions, are usually out of question in such participatory processes.

As a contrast to institutional processes of citizen participation, this article presents an experience of AvR in which a high autonomy and an explicit aim of providing new knowledge were its key features. The AvR process was conducted within the squatters' movement of Madrid along two and a half years (2008-2011). Both valuable political and methodological lessons can be learned from it. Instead of a detailed explanation of the context, practices and challenges faced by the Madrid squatters, we focus here on the methodological aspects of the AvR process carried out. In the next section we introduce the key issues and concepts involved in AvR. We then examine the main significant decisions taken along the AvR process within the Madrid squatters. Accordingly, we distinguish three dimensions that made possible the coherence and efficiency of this particular AvR -self-management, copy-left and qualitative inclusion of social diversity. The final discussion focuses on the outcomes and limits of this autonomous participatory process.

\section{Challenges, Risks and limits of Activist-Research}

The closer a participatory process is to direct democracy, the higher are the risks of unintended effects. Promoters of citizens' participation must accept that the initiatives, proposals and actions brought about by participants, may conduct the process through very unexpected paths. Autonomous groups such as political squatters claim for a radical change within the capitalist system. They do practice direct democracy in wide parts of their everyday lives. Squatted houses and social centres use to be managed by regular assemblies. Within the squatted spaces many smaller groups come together, based on similar horizontal ways of organisation, in order to promote meetings, parties, workshops or cultural activities. People who attend squats are also encouraged to participate as much as they like, although every squat is based upon different formal and informal rules (Pruijt 2004, Domínguez et al. 2010, Piazza 2011).

In squats there is a permanent tension between openness and closeness. While most groups are apparently open to the incorporation of new members, this is a very slow process of getting in touch, building mutual trust and sharing efforts in multiple activities. The same apply to researchers who are not familiar with the squatting milieu. An AvR process within a squat or a local squatting movement demands, thus, a high degree of previous involvement of those who promote it. Newcomers and sympathisers are welcome, but,at least in Madrid, there is no way for starting an AvR if no squatters or former squatters take part in the endeavour. For such a purpose, activist background, as we verified, is more valued and credited than a scientific background, although the latter may add legitimacy to the project. Therefore, AvR within squatting requires a previous 'synergy' rather than 
just a forthcoming one (Martínez 1997). Otherwise, we would face the risk of launching an AvR without the participation of activists.

The second risk at play is the controversial definition of what knowledge means in such a context. Both activists and activist-researchers must accept that an AvR process is able to produce general knowledge as well as 'critical knowledge'. By the latter we mean that common assumptions, stereotypes, hidden episodes and self-identities may be challenged by the results of the research. That is to say, no-one ought to expect that a self-research produces a rough self-legitimation of the social movement in which the process is developed (Offe 1985, Zamosc 1992: 118). Consequently, the movement's weaknesses, troubles and past declines have the chance to be discussed and subjected to public examination as much as the strengths, the legitimate aspirations, and past achievements.

The issue of knowledge is a very controversial one in PAR traditions. Critics of PAR and AvR claim that these approaches lack objectivity, neutrality and methodological standards. Our own standpoint about these criticisms may be summarised as follows (Fals Borda 1985, Martínez 1997, Villasante 2006).

First, activist-researchers need to produce some degrees of objectivity in order to claim that they are knowing anything outside their own lives or from inside. However, while objectivity implies some personal distance from the objects of knowledge, these may vary a lot. Therefore, variations from human words to human behaviours and to social events, entail different capabilities to objectify. Some of them are easier than others in terms of allowing an objective account. On the contrary, some of them demand a more in-depth effort of interpretation in which the researcher's subjectivity play a substantive role. The same may be applied to the social sciences in general, so this is not just a problem of both PAR and AvR (Galtung 1977).

Every researcher determines the objects and subjects of research according to previous social categories. Among them, political or ideological preferences are as legitimate as others. Resulting objectivity is neither absolutely defined nor valid forever because it is always subjected to new criticisms, to improved measures and to qualitative assessments paying attention to different aspects of the issue. AvR, indeed, is a methodological device which does not disguise these problems. Rather the opposite, activist-researchers are opened to the contributions of all kinds of participants in order to define as accurate as possible the type of issues and concerns which are investigated. Public deliberation is not only a democratic situation, but also a technique to contrast and verify previous research results. Equally, the more qualified activist-researchers are those who can contribute to the methodological standards required in order to conduct the process of research.

Secondly, neutrality cannot be claimed as a universal value of social sciences. Absolute neutrality is impossible. Consider, for example, the fact that conventional researchers are tied to the funds, the rules and the definition of problems made by they institutions and social elites who support the research (Pollack 1980). Given that, we could find more freedom in activist-researchers who do not depend so strictly on those institutions while, 
at the same time, they try to practice an explicitly value-oriented research in agreement with the political organisations and movements with whom they work. This, of course, may also impose some constraints on the research but it is a matter of empirical test whether the academia or the movement erodes more the researchers' autonomy. At the end, any external constraint reduces neutrality. The point is how to preserve the researchers' and activists' decisions from the influence of those who do not participate in the AvR itself.

The third peril faced by AvR is its disconnection with social change. In our case, due to the various degrees of involvement, not all the activist-researchers are used to engaging in direct actions against the capitalist system as squatters intentionally pretend to do. Every AvR develops with its own rhythm and pace. These can differ substantially from those of the activists-squatters in our case. How to bring about significant and agreed changes through AvR? As mentioned above, a process like this entails mutual learning and coordination, so that a careful planning of actions for change should deal with that basic core of uncertainty. The actions would even fall within the ambiguous scope of either "social action" or isolated "claims" without greater implications in terms of the models of political organisation of the collective, the positions and interactions with other political actors -all this including the models of society that activists-squatters defend.

As we shall see later, our case study was based on the agreement that we were setting up the "action" of writing a book about the history of squatting in Madrid. In addition, the intention of raising political debates and contributing to strategic reflections and mutual-aid among different groups of squatters in Madrid was openly manifested from the very beginning. In this case there was no other social or political change strictly defined in advance, but the range of options was not closed at all (Petras and Porpora 1993). Thus AvR, at its basic level, could be understood as one academic work performed within the movement, rather than a necessary set of actions to improve current struggles. Even when we tried to avoid this danger (the absence of "high level" actions) and the consequent asymmetry between activist-researchers and regular activists, the lack of a horizon of political action, apart or stemming from squatting itself, drew a striking limitation in this particular AvR.

Many authors have noted that PAR is committed to both the production of knowledge and the improvement of grassroots organisation. This goes far beyond the empowerment of activists or the promotion of occasional socio-economic, educational or cultural interventions. Genuine and ambitious PAR (and so would do AvR) "is committed to achieving structural change objectives" (Fals Borda 1985: 72), "the empowerment of the people so that they can change the environment (both social and physical) to their benefit (...) and the re-establishment of the status of popular wisdom and its promotion." (Rahman 1991: 26) Notwithstanding, activist-researchers would reject political leadership of the processes (Gianotten and De Wit 1991: 109-113). They are expected to engage in political action as much as activists are expected to engage in AvR, by learning about methods and theoretical insights - even though a gap between both would always remain. 
Facing these problems, there is the option of reducing the scope of changes. This can be done by focusing on the group who launches the AvR or, even broader, on the groups of activists who are called to participate. Some authors proposed the rule that 'analysers' instead of analysts are the guidance of a self-managed participatory process (Lapassade 1980: 194). 'Analysers' are social problems, real practices, conflictive events and contested institutions which emerge in a participatory process and scale up the agenda of urgent issues. Once they are identified or discovered, participants' efforts are addressed to deal with them and to explore practical ways of acting as attempts to solve them, if possible. Whether these analysers urge immediate and feasible actions, whether they point to macro-structural spheres of society, they would have the capacity of conducting the AvR in a fruitful manner.

The last theoretical remark in this section has to do with the boundaries and grey zones between AvR and institutionalised participatory processes. AvR consists of a scientific work done by activists with different degrees of political commitment and scientific qualification. As we argued, the group of activist-researchers is based on a wide autonomous self-management of the process. This enables autonomy in regards to external institutions -State or market powers, no less than other civic organisations and social movements. However, there are certain degrees of dependency on the movement to which activists belong.

In the case of the squatters' movement, direct democracy is a basic feature of their internal organisation, this being also adopted by any AvR developed from within this movement. AvR involves some sort of political action as well. This can be reduced to the popularization of the knowledge produced, or, going further, can be expanded to the design, discussion and promotion of direct actions following the scientific results (Zamosc 1992: 120-121). As Conti (2004: 56-59) argued, activists should lead the process in order to create a useful, critical and realist language, only to increase the power of cooperation, organisation and political strategies aiming at their emancipation. Through workshops and publications, for instance, some starting points can be drawn up, but the ulterior trajectory of the process is opened to modifications at the light of producing "new capabilities to fuel practices" (Situaciones 2004: 102).

Institutionalised participatory process, on the contrary, embodies hierarchical structures of power, strict procedures for the allocation of funds and a plural composition of groups as participants. Hidden agendas of authorities and elites can be also playing a very influential role in the process. Although the evolution of the process is also open and able to include emerging proposals, political actions use to be delegated on representative and elected bodies. Thus, both institutional participation and conventional research tend to precede collective action, if action happens at all. Explicit political actions are not performed at the same time as the process of participation is developed. In this context, consultancy and deliberation devices are hegemonic among the participatory techniques to be implemented, while other means to raise political consciousness and to provoke campaigns of mobilization are not so promiment. Hence, one-dimensional views of citizen participation either without regarding the relevant contexts of social inequalities at 
play (Eckardt 2011, Martínez 2011a) or just avoiding social movements' activities (Malo et al. 2004: 156-160), prevent eventual AvR.

Nevertheless, according to Villasante (2006: 306 ) the last opposition is a very narrowminded one since there are multiple axis and combinations of practices for making a participatory process. In particular, he distinguishes between three main "waves" of participatory techniques, depending on their respective scope: 1) "short-waves" involving dialogues, instituent analysers, 'transductive' analysis, operational groups and 'reversive' self-learning; 2) "middle-range waves" connecting micro and macro dimensions of society, horizontal strategies of research, network analysis and sustainable-participatory democracies; 3) "long waves" dealing with the 'creative devolutions' of knowledge, semiotic analysis, the focus on needs and satisfiers, and the claims put on by the global justice movement. Villasante's stance is that any specific participatory process should be designed or evaluated through the strategic combination of these three methodological scopes. Usually, this combination is not absolutely separated from dominant social, political and economic institutions. At least, it involves some basic interactions between researchers, activists and institutional bodies. Hence, there appears a grey zone of several 'reversive' positions and arrangements between extreme autonomous and extreme institutional positions.

Additionally, we contend that the autonomy of collective self-research is also dependent on its members' conditions of living. If they are attached to State or market institutions (for instance, as faculty staff in the university or as freelance professionals), their participation in the AvR may involve different types of interests and some may be presented in overt mutual contradiction. On the other hand, an institutionalised participatory process might be transformed into a more self-managed one in case some independent associations and groups of citizens force the elites to attend their social needs and their demands. Neither AvR or institutional participation are free of unintended consequences, although their points of departure display quite different likeliness of things to happen.

\section{Methodological decisions of an Activist-Research eXPerience}

\section{Starting AvR within a significant context}

First of all, we must present very briefly the evolution of squatting in Madrid. Initial experiences of squatting in Madrid can be found in the late 1970s as part of the citizen movement (Castells 1983) and the anarchist union CNT who demanded a fair treatment comparable to the other labour unions. The major unions received buildings and resources by the authorities as a compensation for their properties seized by the previous Dictatorship. The squatters' movement started to develop in Madrid in the mid and late 1980s, but its main expansion occurred in the decade of the 1990s. Most of the squats publicly known were Social Centres, although some squatted houses were also claimed 
and provided a basic resource for the squatters' movement. Autonomists and different groups of social anarchists (rarely associated with the anarchist unions) (Wilhelmi 2000) launched and ruled most of the squats. However, different social groups of youngsters, neighbours, artists and leftist activists in other social movements also approached and joined the squats (Martínez 2002).

After 1995 a new penal legislation prosecuted squatting and increased the punishment of this political practice. The heavy wave of criminalisation and the short duration of many squats provoked a notable crisis in the squatters' movement during the first half of the 2000s, with the exception of few remarkable cases. Recently, at the end of the last decade, starting around 2008, a new explosion of squats in Madrid took place simultaneously and brought with it a greater diversity of experiences, actors, ideologies and cultural references. As a novelty, three squats were even legalised (Domínguez et al. 2010). After the May-15 Movement (2011), a new wave of numerous squats, both Social Centres and houses, placed squatting again in the public agenda of Madrid, with new generations of activists incorporated into the movement.

In such a context we started up our AvR in October 2008. At that time, a modest campaign for defending squats was launched in Madrid. Within that frame, some debates, parties and demonstration took place. However, the campaign ended suddenly and no further coordinations between different squats took place. Our own project was born independently from that campaign and attempt of coordination but was very closely related to. AvR was promoted by a university professor of sociology (one of the authors of this paper) within a new squatted Social Centre in downtown Madrid. The name of this squat was Malaya to indicate that the owners were immersed in an enormous case of municipal corruption (in the city of Marbella). The AvR proposal was approved by the general assembly of the squat. It consisted in a monthly seminar to debate about squatting with the ultimate purpose of writing a collective book on the history of squatting in Madrid. Around twenty people attended the first meeting. Few people were contacted purposely while most of the participants came on their own, attracted by the ads that were spread out. The group included university researchers, former and present squatters, university students, activists of other social movements and sympathisers with squatting in general. As the leaflet of the initial call, mainly distributed through independent media, stated:

'We suggest to rewrite the history of the squatters' movement in Madrid going beyond the accumulation of data about past experiences, trying to reveal the crucial debates that occurred, the achievements, the conflicts and the different stances at play. All the participants in the seminar are capable to decide how to proceed. (...) The writing of a book or any audiovisual document is an opportunity to trigger in-depth social and political debates among activists, both former and current squatters. There is no intention of becoming the official speaker of the squatters' movement nor of any particular squat. Instead, the seminar aims to reflect collectively about facts, tendencies and strategies which were relevant for the movement."

(1 ${ }^{\text {st }}$ call to the Seminar on the Political and Social History of Squatting in Madrid) 
Knowledge production was as explicit as the intention of gathering different types of squatters in order to share and debate about their ideas on squatting. A book on the social and political history of squatting seemed to be an adequate product in which to materialise that goal - knowledge from a diverse range of insiders' perspectives. The participants in the seminar formed an autonomous group themselves with the power to decide subjects of discussions, who would be invited to talk, and how to distribute the resulting information. The seminar itself became one of the several self-organised groups within Malaya and acquired identical responsibilities as other groups attached to the selfmanagement of that squatted Social Centre. Notwithstanding, only the promoter of the seminar joined the assembly of this and two of the following Social Centres where the seminar was hosted.

The squatters' movement in Madrid never experienced a regular or formal coordination. There were some attempts in the past when some squats were evicted, calling for a demonstration or joining together in direct actions and debates. Informal ties showed to be stronger than both the apparent ideological conflicts among squatters and the various attempts of failed coordination. The continuous replacement of activists and the different waves of evictions did not help much. During the 1990s an autonomist organisation, Lucha Autónoma, was closely involved in many squats (Wilhelmi 2000). Some famous Social Centres also produced valuable texts and reflections, while serving as references for new generations of activists and attendants to squats (Martínez 2002). During the 2000s the squatters' movement endured some internal splits over the issue of turning squats into legal status through agreements with the municipal government. Given this background, the purpose of the seminar was to establish an open situation for the meeting of all types of squatters. Nevertheless, this was too optimistic. Most of the seminar attendants had affinities or previous contacts with the Social Centres where we met, including a high degree of social diversity among them in terms of ideological positions, political experiences and age. From the very beginning, it was decided to invite selected people to debate with the seminar's participants on a regular basis. The group also agreed upon the 'copy-left' character of the information produced by the seminar as it is explained below.

Another relevant aspect of this process is the support and collaboration of different activist groups beyond the seminar's participants. Above all, we enjoyed the space and resources provided by Malaya during the first months as well as by four other Social Centres in the inner city during the next two years (Patio Maravillas I and II, La Mácula and Casablanca). A non-profit organisation, Nodo50 (www.nodo50.org), provided us with free access to an e-mail list. In January 2009 the first meeting of SqEK (Squatting Europe Kollective), jointly promoted by several members of the seminar, was hosted by an independent bookstore, Traficantes de Sueños (www.traficantes.net), run by former autonomists and squatters. Later on, Diagonal (www.diagonalperiodico.net), a bi-weekly journal devoted to social movements, included in their website a banner calling for contributions of documents and personal testimonies to the seminar. Lastly, another friendly website, www.okupatutambien.net, displayed information about the seminar, and many indepen- 
dent media publicized information about each forthcoming meeting (http://madrid.indymedia.org/, www.otromadrid.org/, www.kaosenlared.net/, www.klinamen.org, etc.).

This network of mutual aid was enriched with the conference (April 2010, Patio Maravillas) given by a SqEK member, Alan W. Moore, about his current project on European Social Centres (http://occuprop.blogspot.com/), the exhibition (from April 2010 up to day, at Casablanca) of black and white photographs about squatting in Madrid made by Álvaro Minguito (www.alvarominguito.net), and the organisation of a theatre play (Pieza didáctica de las ocupaciones) directed by César de Vicente Hernando and his company Konkret (September 2010 at Casablanca). Other SqEK members -Hans Pruijt, Thomas Aguilera, Andre and Edward Dee- also presented their views on the 'institutionalisation' issue in a public talk at the CSOA Casablanca (February 2012). Apart from them, we called special guests (former and present squatters, above all, but also one historian, two lawyers and one journalist) to contribute to the sessions of the seminar. With the exception of some internal meetings where we distributed tasks to do, all the sessions of the seminar were open to the free attendance of interested people. We could estimate this participation in around 300 people in total. Five out of the fourteen public sessions were particularly crowded (between 30 and 80 people) probably due to the themes under discussion: legal issues, squatting for housing ( 2 sessions) and gender relations (2 sessions). Significantly, these five events dealt less with historical accounts of the squatters' movement than with the present concerns about squatting. On the other hand, no more than 10 people attended four of the sessions.

After the last public event of the seminar in September 2010, the activist-researchers who conformed the core of the seminar kept in touch through e-mail and met several times along the next year in order to fulfill the objective of writing collectively a book (or e-book). Two more people, who were previous participants in the seminar, contributed to this final stage of the AvR with the edition of some texts. Furthermore, edited texts were sent to the guest speakers asking them for a revision of their words before these were spread out. Some chapters and final tasks had no volunteers in charge so a university student, and former member of the seminar, was paid to finish them -money came from a publicly funded research project.

\section{Key methodological dimensions of AvR}

We consider that three methodological pillars sustained this process of AvR and were crucial for its development and acceptance within the squatters' movement:

1) Self-management and openness. Although there were initial proposals about the contents of the research, at each session all the participants were able to suggest changes, to express their opinions and to commit to the agreed tasks to be carried on. The subscription to the e-list drew a line between those more engaged in the whole process 
and those who just joined one or several public sessions. Only after attending a face-toface encounter could one claim to join the e-list. In general, everybody was invited to get more involved and to attend the organisational and closed meetings as well.

We distributed to the core group the communication activities regarding the announcement of the public sessions, the contact with guest speakers, the writing of questions to be used during the debates, the role of introducing and coordinating every public talk, and, finally, the edition of texts. In practice, this group was made up of around eight people, although an average of twenty became registered in the e-list. Nobody from outside the group could have an influence on the opinions and decisions made without joining the group and commit him/herself in the regular work. This means that the group behaved widely autonomously from even the Madrid squatters' movement and the particular assemblies of the squats where we met.

Self-management implied a horizontal way of facing the work at every meeting. That is to say, no structured hierarchy was behind, although a practical one always emerged due to the greater or lesser dedication of every member. Since it was a complete voluntary-run, militant and non-for-profit work, every participant decided to be in charge of tasks according to his/her own will, capabilities and availability. Horizontality and openness meant here that everybody was welcome to join and to participate with equal rights. We tried to make transparent both our own affiliations and the initial goals of the project. These might be discussed too and, as a matter of fact, they were refined and modified throughout the process. Deliberation entailed cooperation and negotiation too. Within this frame, decisions were made according to the criteria and arguments expressed by the participants. The final goal of writing a collective book mainly based on the transcripts of the debates as a sort of general and descriptive picture about the squatters' movement helped avoid fierce discussions and controversies.

Finally we also worked under a very low-cost scheme. Beverages, snacks, photocopies, one e-banner as an advertisement of the seminar, the transcriptions of the talks and one professional final edition of the book were the only major expenditures. Most of them were paid with the budget of a research project that one of the seminar members had available at his university. Two other members participated in a university workshop and also contributed to the seminar with the money they got. Other small donations were received. We planned a party in one of the squatted Social Centres in order to collect some funds, but a sudden eviction aborted the plans and we never tried that way of fundraising again.

2) Collective production and free access to knowledge. The seminar relied on collective debates rather than on individual contributions. Previous classic research on squatting was inspiring but seemed to produce unintended effects on activists who did not use it or just refused it due to the academic distance it created. Thus, the new attempt consisted in setting up a mix of different activists and a few professional researchers who were able to create a new collective narration about crucial facts, events and views on squatting. 
Initially, the design of the whole process of AvR foresaw the implementation of conventional methods of social research such as personal interviews, discourse analysis and statistical records. However, once we started to work technically, we discovered that the required skills, resources and personal dispositions overwhelmed ours. Therefore, we decided to focus on the public debates as the principal devices for the collective production of knowledge. The debates were lightly conducted and moderated through the questionnaire we prepared the days before each of them. The guests' presentations, participants' opinions and interactions held were just dependent on the constraints of time and mutual respect that someone tried to take care of. The more we focused on these public sessions, the more we gave up the efforts devoted to conventional research methods. The latter had the added problem of time availability and technical qualification, which were too demanding for many of the seminar fellows.

On the other hand, the social activities we organised - such as the talks about squatting in Europe, the photo exhibition and the theatre play-, the contacts with former squatters and the dissemination of the calls to the seminar meetings, were easier to develop for most of the participants. In addition, all of these activities were sources of valuable information about the history of squatting and enriched the participants' knowledge. Almost without noticing, we ended connecting social networks of activists and invigorating the public debate on squatting.

Closely related to this approach, we all agreed upon the distribution of all the registered debates under a copy-left license. This means that all the outcomes of the seminar would be freely available for non-commercial purposes and could be replicated, quoted and spread out extensively. To us, this attitude was coherent with the libertarian and autonomous ideology which is prevalent within the squatters' movement and it served as a transparent way of asking for the voluntary contribution of everyone according to his/her abilities and knowledge. By claiming copy-left licenses it is recognised that a great part of the work is really made collectively and no individual author is the exclusive producer of the information collected in the book. However, these licenses also entail that individual contributions are explicitly acknowledged and can hold their respective authorship rights. Copy-left licenses, and the whole open-source movement, just ask the authors to share their products to the extent that others can reproduce them and use them without paying for it, unless both parts agree on any payment regarding the costs of the means used for distributing the information -take for instance, the printing costs of a book. It is a matter of choice for the authors to protect their rights as authors by either using copy-left or copyright licenses, but in the seminar we encouraged the former and there was no particular objection to that.

3) Qualitative and comprehensive approach. As we mentioned before, a relevant internal diversity within the squatters' movement is a feature that cannot be let aside. Otherwise, we will produce a very partial account. Rough pictures about this movement are usual in the mass media and, less frequently, in conventional academic research. Hence, one of the first aims of the AvR process was to accept this diversity, to uncover 
it and, if possible, to integrate it in the debates we promoted. This implied to focus on the different subjective experiences and political orientations, not less than on significant conflicts and assessments about both the evolution and the impacts of the movement.

Instead of offering a unified image of squatting, we opted for collecting a manifold view which could include self-criticisms and opposing interpretations. On the one hand, the research should emphasise a public recognition of all the social and political complexity involved in squatting. On the other hand, we preferred to show raw differences and conflicts without pretending to represent a fake consensus among participants. We supplied every session with all the knowledge we previously had in order to provoke debates and make explicit practices, discourses, events and actors of the squatters' movement. The final edition of the transcripts was made with the same purposes in mind.

This is a methodological option that consists on giving priority to qualitative and comprehensive information because, we argued, we could thus encourage people to appropriate knowledge and generate a new one. At the end, the book is basically a very descriptive collection of the debates after a careful edition of the texts and the addition of short qualified texts about the issues at stake. The main advantage of this technique, compared to the gathering of quantitative stuff, is that participants have more room to contribute and to orientate the interpretations of meanings. From the conventional standpoint of social sciences, what we made was a combination between group interviews and participant observation. Most of the participants were used to these open debates in many squats so the research objectives and the previous organisation of each session were just additions to a common practice among squatters and sympathisers.

The final step of the process was the edition of the book. This endeavour had a three-fold dimension: a) to improve the texts with additional information about events, cases or references; $b$ ) to select the most relevant parts of the debates in order to ease the final reading; $c$ ) to allow all the participants with whom we were in contact (through email or phone) to revise their opinions and intentions in advance of the final publication. Activist-researchers also added introductory texts in order to improve the context and understanding of each session. These were submitted to internal review by other seminar members.

\section{Conclusions}

AvR is one of the branches of PAR. Both share a common tradition of gathering together politically engaged social scientists side-by-side politically engaged workers, activists and deprived groups. Beyond this coalition, 'scientific militancy' or 'militant science' entails a specific methodological complexity on its own that deserves a careful attention. Our case study serves to illustrate the key points of this participatory and activist methodology.

First of all, AvR is a matter of social interaction between identities on the move. None of the participants keep a unique feature to define his or her identity, but several strands from outside and inside strive to be expressed. Neither the pure activist, nor the pure 
researcher exist in a participatory process like this. Therefore, identities are continuously negotiated and modified along the process. Once everybody accepts that the research is made for the sake of activism, activists start to develop or adopt some research skills. In parallel, researchers need to adapt their scientific standards to the concrete ends that are deemed to be achieved and the specific circumstances of the situations where the AvR is developed.

The AvR process should empower all the participants. The main way in doing so is by urging them to reach agreements about the level of depth of the knowledge to be produced and their degree of involvement in the movement's current activities. What stems from our case is that a basic activist trajectory or, at least, a proved connection to the squatting scene was necessary to launch the AvR process from within a particular squat. Once the process started, it was open to a wide range of people with different activist or scientific backgrounds. Everybody who attended was able to deliberate and make decisions collectively. It seems inevitable to divide the group into a core and a more volatile cloud of occasional participants, this implying a certain practical hierarchy although there were no explicit barriers to move from one side to the other.

Secondly, the context also matters. The squatters' movement is a radical and leftist one, embedded in particular subcultures and countercultures (Koopmas 1995, Martínez 2002). Sometimes social sciences are seen by squatters as academic exercises from outside the movement, full of bias and with little substantive interest for the political debates among squatters. Nonetheless, some useful documents and books were produced by squatters themselves - usually, holding university degrees - or by sympathetic researchers (for example, VVAA 1997; VVAA 1999; Wilhelmi 2000; VVA 2001; Adell, Martínez et al. 2004; Toret et al. 2008, Domínguez et al. 2010). While most of these writings share with our process a copy-left and a respectful attitude to the squatters' movement -without necessarily avoiding self-criticisms-, the process of production differs significantly.

As mentioned above, political coordination between the Madrid squats had been scarce and experienced multiple troubles. Our AvR actually intended to increase bonds between different types of activists. Self-research about their own history was suggested as the arena where this enriched social network could emerge (if not a proper formal coordination), although this exceeded our expectations. Thus, we were both cautious and active within this particular context. Indeed, we found out that there was a strong attachment towards our seminar within the Social Centres where we met. Additionally, we also verified that a political coordination was not in the agenda of most of the Madrid squats at that period. These were evident boundaries to take into account along the AvR process.

Thirdly, the aspects of this context that we have already highlighted had a great influence in our capacity to act politically. The main results of the seminar were basically, to meet, debate and publish a lot of information about squatting in Madrid. Some of the issues (such as the historical roots of the movement, detailed legal aspects and the conflictive gender relations, for instance) were rarely reported in previous publications and 
the seminar contributed to enlarge the knowledge about them. This means that research took priority, at the end, over political practice, unless we consider that the autonomous and committed way of doing AvR was undoubtedly a politically-oriented practice. Given our participation in the five squatted Social Centres that hosted us, this did not result in a substantial increase of the engagement in squatting of most of the core members. Those who already were engaged, remained, but there were no new incorporations. The other way around was also left unexplored since the most active squatters of these squatted spaces did not feel too attracted by the research-centred work of the seminar. Notwithstanding, the group of activist-researchers kept its wide autonomy and enhanced the mutual knowledge and informal ties with hundreds of squatters and sympathisers, which can be regarded also as a practical consequence of the experience.

The kind of reflexive methodological approach that this AvR entails is similar to that of the collaborative and activist ethnography (Rappaport 2008, Schensul et al. 2008, Hale 2006) while is not so close to the problem-solving or pragmatic approaches (Greenwood 2007). As many of those practitioners argued, included most of the pragmatists, the choice of this method is not only a matter of moral or ideological values, but also a rational choice according to the special qualities of the human group under observation or, better, self-observed. However, AvR is a tool of reflexivity guided by a small part of the whole group -the squatters' movement. Hence, the environment of relationships between activist-researchers and activists sets a limit to the actual autonomy of the process, and it also shapes the adequate approach to know the social reality (Chambers 1997, Malo 2004, Villasante 2006, Fuster 2009). Participants in AvR, as conscious agents of those relationships, take collective decisions along the process. Although some starting points and crucial decisions may be adopted at the beginning, a lot of improvisation and discussion about further steps occur in the next stages.

\section{REFERENCES}

Adell, R. and M. Martínez. eds. 2004. ¿Dónde están las llaves? El movimiento okupa: prácticas y contextos sociales. Madrid: La Catarata.

Arnstein, S. 1969. "A Ladder of Citizen Participation." Journal of the American Planning Association 35 (4): 216-224.

Blackburn, J. and J. Holland. eds. 1998. Who Changes? Institutionalizing Participation in Development. Exeter: Intermediate Technology.

Borja, J. and M. Castells. 1997. Local y Global. La gestión de las ciudades en la era de la información. [Local and global. City management in the age of information] Madrid: Taurus-United Nations for Human Settlements (Habitat).

Cancian, F. M. 1993. "Conflicts between Activist Research and Academic Success: Participatory Research and Alternative Strategies." The American Sociologist 24-1:92-106. 
Castells, M. 1983. The City and the Grassroots. A Cross-Cultural Theory of Urban Social Movements. Berkeley: University of California Press.

Chambers, R. 1997. Whose Reality Counts? Putting the First Last. London: Intermediate Technology.

Conti, A. 2004. "La encuesta como método político. El objetivo de la encuesta no es la interpretación del mundo sino la organización de su transformación." Pp. 55-66 in Malo, Marta edited by Nociones comunes. Experiencias y ensayos entre investigación y militancia. Madrid: Traficantes de Sueños.

Cox, L., and C. Flesher. 2009. "Movement knowledge: what do we know, how do we create knowledge and what do we do with it?" Interface: a journal for and about social movements 1(1):1-20. [http:/l www.interfacejournal.net/2009/01/issue-one-editorial-movement-knowledge.html]

Cox, L. 1998. "Gramsci, movements and method: the politics of activist research." Alternative Futures and Popular Unrest: 4th International Conference, Manchester Metropolitan University. [http:/l eprints.nuim.ie/442/]

De Sousa Santos, B. ed. 2003. Conhecimento Prudente para uma Vida Decente. Um Discurso sobre as Ciências revisitado. Porto: Afrontamento.

Domínguez, M., Martínez, M. and E. Lorenzi. 2010. Okupaciones en movimiento. Derivas, estrategias, prácticas. Madrid: Tierra de Nadie.

Eckardt, F. 2011. "Cuando la gente se hace oír... Reflexiones sobre el renacimiento de la democracia directa en Alemania." Urban 1:67-80.

Fals Borda, O. 1985. Conocimiento y poder popular. Lecciones con campesinos de Nicaragua, México, Colombia. Bogotá: Punta de Lanza-Siglo XXI.

Fuster, M. 2009. "Action research: mapping the nexus of research and political action." Interface: a journal for and about social movements 1(1): 21-45 [http://www.interfacejournal.net/2009/01/activistresearch-methodologies_9685.html ]

Galtung, J. 1977. Methodology and Ideology. Theory and Methods of Social Research. Copenhagen: Christian Ejlers.

Gianotten, V. and T. De Wit. 1991. "Un caso de organización popular." Pp. 89-114 In Acción y conocimiento. Cómo romper el monopolio con investigación-acción participativa edited by Fals Borda, O. and Rahman, M.A. Bogotá: CINEP.

Greenwood, D. 2007. "Pragmatic Action Research." International Journal of Action Research 3, 1/2: 131 148.

Hale, C. R. 2006. "Activist Research vs. Cultural Critique: Indigenous Land Rights and the Contradictions of Politically Engaged Anthropology." Cultural Anthropology 21-1: 96-120.

Jimeno, M. 2004. "La vocación crítica de la antropología latinoamericana." Maguaré 18:33-58.

Koopmans, R. 1995. Democracy from Below. New Social Movements and Political System in West Germany. Colorado: Westview.

Lapassade, G. 1980. Socioanálisis y potencial humano. Barcelona: Gedisa.

Malo, M. ed. 2004. Nociones comunes. Experiencias y ensayos entre investigación y militancia. Madrid: Traficantes de Sueños. 
Martínez, M. 1997. "Dimensiones epistemológicas y metodológicas de la IAP para un autoconocimiento de los Nuevos Movimientos Sociales." Política y Sociedad 25: 205-227.

Martínez, M. 2002 Okupaciones de viviendas y centros sociales. Autogestión, contracultura y conflictos urbanos. Barcelona: Virus.

Martínez, M. 2011a. "Dimensiones múltiples de la participación ciudadana en la planificación espacial." Revista Española de Investigaciones Sociológicas 133: 21-42.

Martínez, M. 2011b. "The Citizen Participation of Urban Movements in Spatial Planning: A Comparison between Vigo and Porto." International Journal of Urban and Regional Research 35-1: 147-171.

Offe, C. 1985. "New Social Movements: Challenging the boundaries of institutional politics." Social Research 52, 4: 817-68.

Park, P. 1992. "Qué es la investigación-acción participativa. Perspectivas teóricas y metodológicas." Pp. 135-17 in La Investigación. Acción participativa. Inicios y desarrollos, edited by Salazar, M.C. Madrid: Popular-OEI-CEAAL.

Petras, E. M. and D. V. Porpora. 1993. "Participatory Research: Three Models and an Analysis." The American Sociologist 24-1:107-126 .

Piazza, G. 2011. Which models of democracy? Internal and external decision-making processes of Italian Social Centres in a comparative study. Center of Studies on Politics and Society - WP Series 1-1, pp.3-54.

Pollack, M. 1980. "Paul F. Lazarsfeld: A Sociointellectual Biography." Science Communication 2:157-177.

Pruijt, H. 2004a. "Okupar en Europa." Pp. 35-60 in ¿Dónde están las llaves? El movimiento okupa: prácticas y contextos sociales, edited by Adell, R. and M. Martínez. Madrid: La Catarata.

Rahman, M. A. 1991. "El punto de vista teórico de la IAP." Pp. 21-35 in Acción y conocimiento. Cómo romper el monopolio con investigación-acción participativa. edited by Fals Borda, O. and Rahman, M.A. Bogotá: CINEP.

Rappaport, J. 2008. "Beyond Participant Observation: Collaborative Ethnography as Theoretical Innovation." Collaborative Anthropologies 1: 1-31.

Schensul, J. J., Berg, M. J. ande K. Williamson. 2008. "Challenging Hegemonies: Advancing Collaboration in Community-Based Participatory Action Research." Collaborative Anthropologies 1: 102-137.

Reason, P. 1994. "Three Approaches to Participative Inquiry." Pp. 324-339 in Handbook of Qualitative Research, edited by Denzin, N., Lincoln, Y. London: Sage.

Shukaitis, S., and D. Graeber. 2007. Constituent Imagination. Militant Investigations, Collective Theorization. Oakland: AK Press.

Situaciones, Colectivo. 2004. "Algo más sobre la Militancia de Investigación. Notas al pie sobre procedimientos e (in)decisiones." pp. 93-110 in Malo, Marta (ed.) Nociones comunes. Experiencias y ensayos entre investigación y militancia. Madrid: Traficantes de Sueños. [also included in Shukaitis and Graeber (eds.) Constituent Imagination. Militant Investigations, Collective Theorization. Oakland: AK Press, pp. 73-93].

Toret, J. et al. Eds. 2008. Autonomía y metrópolis. Del movimiento okupa a los centros sociales de segunda generación, Málaga: ULEX y Diputación Provincial de Málaga. 
VVAA. 1997. Kontra la nada. Testimonios del Cine Okupado. Barcelona: Kasa de la Muntanya.

VVAA. 1999. Okupació, repressió i moviments socials. Barcelona: Assemblea de Okupes de TerrassaDiatriba-Kasa de la Muntanya.

VVAA. 2001. Vivienda: especulación,... \& Okupazioak, Bilbo: Donostialdeko Okupazio Batzarra - Likiniano Elkartea.

Villasante, T. R. 2006. Desbordes creativos. Estilos y estrategias para la transformación social. Madrid: La Catarata.

Wilden, A. 1987. Man and Woman. War and Peace. The Strategist's Companion. London: Routledge.

Wilhelmi, G. 2000. Armarse sobre las ruinas. Historia del movimiento autónomo en Madrid (1985-1999). Madrid: Potencial Hardcore.

Woolgar, S. 1988. Science: The Very Idea. London: Ellis Horwood.

Zamosc, L. 1992. "Campesinos y sociólogos: reflexiones sobre dos experiencias de investigación activa en Colombia." Pp. 85-133 in La Investigación. Acción participativa. Inicios y desarrollos edited by Salazar, M.C. Madrid: Popular-OEI-CEAAL.

Miguel Ángel Martínez López is Sociologist and PhD in Political Science currently affiliated to the University Complutense of Madrid. He is an activist-researcher involved in the Spanish squatting movement and the M15 movement. He researches in the fieldof urban sociology, social movements and participatory democracy. Most of his works are available at: www.miguelangelmartinez.net.

Elisabeth LoRenzı Fernández is PhD in Social and Cultural Anthropology from Complutense University, Spain. During her career development she observe social movements studies, sustainable development, mobility and intercultural process. These issues are crossed by a deep interest on methodological challenges and applied anthropology. More information about her publications in http://elisabethlorenzi.wordpress.com.

RECEIVED: 10 February 2012

ACCEPTED: 17 October 2012 